\title{
SHORTWAVE DIATHERMY (S.W.D.) IN THE TREATMENT OF UNRESOLVED PNEUMONIA
}

\author{
S. H. M. BLACKWOOD, M.C.S.P., Dip. T.P.*
}

\section{OPSOMMING}

Dit is gevind dat pneumonie in die konsolidasie stadium effektief behandel kan word met kortgolfdiatermie om sodoende resolusie aan te help. Sommige chroniese borskwale, byvoorbeeld asma en emfiseem, vind ook hierby baat. 'n Deur-en-deur aanwending word gebruik en asemhalingsoefeninge moet altyd daarmee saam gedoen word.

How many physiotherapists know the frustration of treating a pneumonia which refuses to resolve. In spite of chemotherapy, postural drainage, percussion, shaking and vibrations, rib-springing, breathing exercises and the patient's own activity, back come the chest radiographs still showing that resolution has not occurred.

Many years ago, when all efforts to clear up a pneumonia in a patient who was herself a doctor had failed, it was decided to try shortwave diathermy. The patient was intermittently febrile and chronically unwell. The resistant patch of inflammation was situated in the anterior segment of the right lower lobe. Application was through-and-through this area with a large malleable electrode placed posteriorly and a medium glass electrode placed anteriorly with close spacing. Initially four mild thermic treatments of fifteen minutes duration were given twice a day for two days. The patient was sent for chest radiographs which showed a marked reduction in the size of the inflammatory patch. A further six treatments were given in exactly the same way for the next three days. At the completion of $t$ course the chest radiographs were clear and the patiel.was feeling well.

As a consequence, over the years SWD has been used routinely by me and now in my practice for unresolved pneumonia. Application has always been as described, the electromagnetic field being directed as nearly as possible through the area of inflammation. It has been found, however, that one daily treatment of twenty minutes' duration is equally effective.

A maximum of six to eight treatments should be given. If there is no change in the size of the pulmonary opacity, then some other lesion is present, possibly sinister, and the patient should be referred for further investigation. Check radiographs should be carried out after three or four treatments and if there is seen to be an increase in the size of the opacity then treatment should be stopped immediately.

As a further consequence SWD was tried for some other chronic respiratory disorders and found to be useful in the treatment of emphysema, asthma and chronic bronchitis. It is NOT used, however, in the

* Frivate Practice, Westville, Natal. Received 16 July 1980. 
presence of infection. Application is again through-andthrough the chest wall with a large malleable electrode placed posteriorly in the upper thoracic region and a medium malleable electrode placed anteriorly over the sternum and pectoral region. Dosage is mild thermic for fifteen to twenty minutes.

SWD applied through the chest unequivocally gives the patient a sense of well-being - perhaps on the deus ex machina principle. It may be that the effect is to relieve bronchospasm, not only to induce more gene- ral relaxation, and it may be that mucus is rendered less viscid; the attribute of SWD of effecting vasodilatation may serve a purpose when used across the lungs or it may serve only to increase the ventilation: perfusion inequality. This might prove an interesting field for research.

There should be no need to stress that other proceciures, such as vibrations and breathing exercises, should always accompany the treatments by shortwave diathermy. 